\title{
Management of sickle cell disease: challenges and risks of transfusion
}

This article was published in the following Dove Press journal:

International Journal of Clinical Transfusion Medicine

7 October 2016

Number of times this article has been viewed

\section{Graham R Serjeant \\ Sickle Cell Trust (Jamaica), Kingston, Jamaica}

Correspondence: Graham R Serjeant Sickle Cell Trust (Jamaica), 14 Milverton Crescent, Kingston 6, Jamaica Tel +l 8769700077

Email grserjeant@cwjamaica.com
Abstract: Homozygous sickle cell (SS) disease is associated with rapid red cell destruction and a tendency to block flow in blood vessels. The bone marrow expansion needed to compensate for the rapid red cell destruction increases metabolic demands and folate requirements but also renders the bone marrow prone to suppression by renal impairment and infections especially those with human parvovirus B19. The abnormal red cells also tend to block blood vessels impairing flow in the bone marrow (dactylitis, bone pain crisis, hip necrosis), the spleen (acute splenic sequestration, chronic hypersplenism, loss of the normal filtering system rendering patients prone to overwhelming septicemia), the lungs (pulmonary embolism, acute chest syndrome), and the brain (ischemic stroke, hemorrhage). Transfusion plays a role in addressing all of these pathologies. During the acute lowering of hemoglobin due to acute splenic sequestration and aplastic crisis and the persistent lowering of hemoglobin due to chronic hypersplenism and chronic renal failure, top-up transfusions may help in maintaining oxygen delivery and symptomatic relief. Addressing vaso-occlusion is more complex but best documented in preventing recurrent stroke and primary stroke following detection of cerebral vessel stenosis by transcranial Doppler. Although top-up transfusions have minimal side effects, potentially serious complications arise from chronic transfusion, and there are many unanswered questions on the duration of such therapy and the natural history of the underlying complications. These issues are addressed with the knowledge currently available.

Keywords: sickle hemoglobin, $\mathrm{HbS}$, transfusion, oxygen affinity, anemia, vaso-occlusion

\section{Introduction}

The substitution of valine for glutamic acid at position 6 in the amino terminus of the beta chain in sickle hemoglobin $(\mathrm{HbS})$ changes the behavior of the molecule. When deoxygenated, molecules of $\mathrm{HbS}$ tend to polymerize and deform the red cell resulting in the principal pathological features of the disease, hemolysis and obstruction of blood flow. The HbS mutations have occurred on at least 3 independent occasions in the African continent, ${ }^{1}$ are named after the areas where they were first described, Benin, Bantu (or Central African Republic), and Senegal, and are known as the beta globin haplotypes. Most of the published knowledge on sickle cell disease has been derived from peoples of West African origin with the Benin haplotype. A fourth independent mutation occurred in the Arabian Gulf and Central India and is known as the Arab-Indian or the Asian haplotype. ${ }^{2}$ This haplotype often has more mild clinical features because it is usually associated with high levels of fetal hemoglobin $(\mathrm{HbF})$ and frequent deletional alpha thalassemia, both factors likely to inhibit intravascular 
sickling. Inheritance of the $\mathrm{HbS}$ gene from both parents result in homozygous sickle cell (SS) disease, which is generally severe and the most common at birth. Inheritance of the $\mathrm{HbS}$ gene along with another interacting hemoglobin variant results in doubly heterozygous conditions, sickle cell-hemoglobin C (SC) disease, sickle cell-beta thalassemia, and uncommon conditions such as sickle cell-HbO Arab, sickle cell-HbD Punjab, and sickle cell-hemoglobin Lepore. These conditions are generally milder than SS disease and often show differences in clinical and hematological expression. The current review is confined to SS disease but often distinguishes between African and Asian forms of the disease.

\section{Steady-state hematology}

The "steady state" refers to when a patient is clinically well and is characterized by hematological features, which oscillate within a narrow range in the same patient but can vary markedly between patients of the same genotype. In African SS disease, mean red cell survival is markedly shortened to 10-12 days, ${ }^{3}$ compared to 120 days in hematologically normal people, and requires expansion and increased turnover of the red cell precursors in the bone marrow. A new steadystate equilibrium (hemoglobin levels $6-9 \mathrm{~g} / \mathrm{dL}$, reticulocyte 10-12\%, red mean cell volume (MCV) 80-95 fL) develops, ${ }^{4}$ knowledge of which is necessary to interpret the deviations from these values. Patients with the Asian haplotype SS disease may have different steady-state values (hemoglobin 8-11 g/dL, reticulocyte counts 3-8\%, MCV 60-80 fL), ${ }^{5}$ consequent on the presumed greater red cell survival associated with high $\mathrm{HbF}$ and frequent alpha thalassemia common in this haplotype.

$\mathrm{HbS}$ within the red cell behaves with a low oxygen affinity with a marked shift in the oxygen dissociation curve to the right (Figure 1). Traditionally described as the p50 (oxygen tension associated with $50 \%$ saturation), values in normal AA

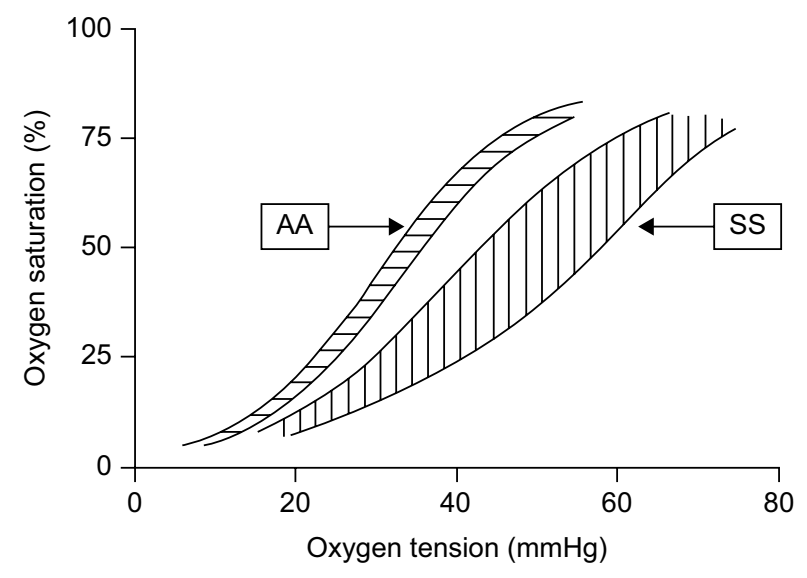

Figure I Oxygen dissociation curves in normal (AA) blood and in SS disease. blood are 29-31 mmHg, whereas in African SS disease, they may range from 40 to $60 \mathrm{mmHg}$. Patients with the greatest shift in p50 tend to have the lower steady-state hemoglobin levels, ${ }^{6}$ almost as if the erythropoietic drive is switched off at submaximal reticulocyte counts. This adaptation implies that hemoglobin level cannot be equated with oxygen-carrying capacity, and it is vital to treat the patient rather than the hemoglobin level.

\section{The role of transfusion}

Blood transfusion may restore the oxygen-carrying capacity in patients with SS disease with symptomatically lowered hemoglobin levels and may also serve to dilute circulating HbS-containing cells reducing the tendency to vaso-occlusion. Deviations from the patient's steady-state values usually reflect a specific pathology requiring diagnosis, since this will determine the role of blood transfusion.

Symptoms of anemia are usually determined by the rate of fall in hemoglobin level which is most rapid in acute splenic sequestration (ASS; falls of 4-6 g/dL in hours), less precipitate the aplastic crisis (falls of $1 \mathrm{~g} / \mathrm{dL} /$ day), and much slower in chronic renal failure and iron or folate deficiency. In chronic renal failure, the lack of erythropoietic drive to the bone marrow is followed by a gradual decline in hemoglobin which may respond to exogeneous erythropoietin (EPO), but is more readily treated by top-up transfusions to maintain oxygen carriage and relieve symptoms. In chronic hypersplenism, the low hemoglobin and the metabolic demands of the greatly expanded bone marrow may be relieved by chronic transfusion programs or more readily by splenectomy. ${ }^{7}$ Infections may suppress the bone marrow response, and infestations such as malaria may exacerbate hemolysis, so transfusions may have a supporting role while the underlying pathology is treated. Nutritional deficiencies of iron, folate, or possibly vitamin $B_{12}$ require treatment which is often followed by a prompt hematological response, although short-term transfusion may be necessary.

\section{Lowered hemoglobin levels - "top-up" transfusion Acute splenic sequestration}

In the past, acute enlargement of the spleen associated with low hemoglobin and increased reticulocytes was a common cause of early mortality. In the Jamaican Cohort Study, attacks occurred as early as 3 months, were most common in the second 6 months of life with a cumulative probability rising from 0.255 by 2 years to 0.297 by 5 years, and were uncommon after 6 years of age. ${ }^{8}$ Events are more common 
in patients with low $\mathrm{HbF}$ levels, ${ }^{9}$ but the precipitating factors are unknown although events may be concurrent in twins. ${ }^{8}$ Recurrence is common, and after 2 attacks, further attacks may occur at shorter intervals, leading to a policy in Jamaica of prophylactic splenectomy after 2 attacks. In the absence of a clear etiology, prevention may not be possible, but mortality can be significantly reduced by parental education on early detection, ${ }^{8}$ which will allow time for transfusion during the acute episode. A single unit of blood, proportionately less for young children, is adequate, since this is frequently associated with a decrease in splenic size and release of sequestered blood which may raise the hemoglobin to unexpectedly high levels.

The use of chronic transfusion to prevent recurrence is controversial. Prophylactic chronic transfusion may have the advantage of restoring or improving splenic function, ${ }^{10}$ but it is unclear how best to monitor or when to stop such chronic transfusion. Well-controlled programs maintaining $\mathrm{HbS}$ levels below $20 \%$ may fail to prevent recurrences of ASS, ${ }^{11}$ and stopping transfusion at age 5-6 years when ASS becomes rare in untransfused patients may be followed by recurrent attacks. ${ }^{12}$ Considering these problems and the difficulties inherent in chronic transfusion, prophylactic splenectomy after 2 attacks of ASS appears to carry less risk, although the 2 approaches have not been assessed in controlled trials. ${ }^{13}$

\section{Aplastic crisis}

Defined clinically as a hemoglobin markedly below steadystate levels, usually to $2-5 \mathrm{~g} / \mathrm{dL}$, and absence of reticulocytes, the aplastic crisis almost always occurs due to parvovirus B19 infection. ${ }^{14}$ This organism destroys the early precursors in the bone marrow for 8-10 days exceeding the mean red cell survival in some patients, and hemoglobin levels fall by $1 \mathrm{~g} /$ day, leading to avoidable morbidity and sometimes death. In most cases, the outcome is benign and predictable, and transfusion may be performed as outpatients with follow-up for 3-5 days later to ensure that the expected reticulocytosis of the recovery phase has occurred. This is manifest by a rapid daily increase in reticulocyte count, which often reaches $30-40 \%$, and the hemoglobin level is quickly restored to steady-state levels. Transfusion of a single unit of blood is adequate to maintain oxygen delivery during this period, but occasionally, the reticulocyte response is delayed and a second transfusion may be necessary. Human parvovirus is highly infective; $60 \%$ of SS patients seroconvert by 15 years of age, ${ }^{15}$ and SS siblings of an aplastic patient should be closely observed as approximately $80 \%$ of nonimmune siblings with SS disease are affected either simultaneously or within 3 weeks. Immunity to parvovirus appears to be lifelong, and recurrent attacks of B19 infection have not been described in otherwise uncomplicated SS disease.

\section{Chronic hypersplenism}

Sustained splenic enlargement with hemoglobin levels below and reticulocyte counts above steady-state levels may complicate SS disease, most commonly between the ages of 5 and 15 years, and occurred in approximately $5 \%$ of the Jamaican Cohort Study. Although the etiology is unknown, red cell survival in hypersplenism is further shortened from the usual range of 10-12 days to 2-3 days with hemoglobin levels of 3-5 g/dL, and reticulocyte counts generally exceeding 15\%. Marked bone marrow expansion increases the metabolic demands, which compete with those of growth and may impair height velocity. The natural history of chronic hypersplenism in SS disease is poorly documented but may resolve spontaneously, although most patients require transfusion to maintain oxygen carriage and relieve symptoms while awaiting signs of spontaneous regression. Such cases are monitored in Jamaica with monthly assessments of spleen size, hemoglobin and reticulocytes, and height and weight with transfusion to relieve symptoms of diminished exercise tolerance. If there is no evidence of spontaneous regression within 6 months, therapeutic splenectomy is usually performed. Elective splenectomy, which avoids the cost and complications of chronic transfusion, has been universally beneficial in Jamaican experience. With pneumococcal prophylaxis which is given for at least 3 years, splenectomized patients do not appear to be more prone to overwhelming blood infection. ${ }^{16}$

\section{Chronic renal impairment}

A progressive glomerular fibrosis causes fall in glomerular filtration rates and lowering of EPO levels, and commonly contributes to mortality in patients with African forms of SS disease over the age of 40 years. Reticulocyte counts and hemoglobin levels fall slowly and are surprisingly well tolerated, with some patients not seeking medical attention until hemoglobin levels reach 2-4 g/dL. Patients may respond to exogeneous EPO, but treatment is expensive, difficult to administer, and because of the expanded bone marrow, unpredictable in its effects. The most economic therapy is regular top-up transfusion to relieve symptoms, which may be achieved with hemoglobin levels in the range of $6-8 \mathrm{~g} / \mathrm{dL}$. In Jamaica, many patients have been maintained for years with simple top-up transfusions, the frequency of which was determined by patient symptoms. 


\section{Transfusion to dilute the circulating sickle red blood cells}

Transfusion may be beneficial in the prevention of stroke and in management of the acute chest syndrome, but there is no convincing evidence of benefit for therapy of the bone pain crisis, perioperative management, pregnancy, ASS, priapism, and chronic leg ulceration.

\section{Central nervous system}

A major pathology in childhood, stroke, affected approximately $10 \%$ of Jamaican Cohort by the age of 14 years, ${ }^{17}$ with a median age at first stroke of 6 years, The pathology is usually ischemic consequent on blockage of major cerebral, carotid, or vertebral vessels. Strokes recur in $50-70 \%$ of patients within 3 years, ${ }^{17,18}$ and chronic transfusion significantly reduces recurrent stroke compared to a non-transfused group. ${ }^{19}$ Transcranial Doppler (TCD) may detect stenosis of major blood vessels before strokes occur, ${ }^{20}$ and a randomized trial of chronic transfusion in patients with TCD evidence of cerebral stenosis showed a highly significant reduction of stroke, ${ }^{21}$ and of persistence of normal TCD indices, ${ }^{22}$ in the transfusion-treated group. Silent cerebral infarcts detectable by magnetic resonance imaging or "soft" neurological signs may also be predictive of further silent infarcts or strokes, and a randomized trial of transfusion over a median period of 3 years showed a marginal statistical improvement. ${ }^{23}$

Although successful in the short term, chronic transfusion therapy raises many problems in long-term management such as its duration, the effects of stopping therapy, and lack of an optimal method of monitoring the effectiveness of chronic transfusion. Most programs are monitored by maintenance of $\mathrm{HbS}$ levels below $30 \%$, but recurrences have occurred with $\mathrm{HbS}$ levels as low as $17-18 \%,,^{24,25}$ and recurrent events, either overt strokes or fresh silent infarcts, occurred in 18 of $40(45 \%)$ children on well-monitored transfusion programs, ${ }^{26}$ and stroke recurred after 11 years on transfusion, ${ }^{27}$ with $\mathrm{HbS}$ levels below $20 \%$. The required duration of transfusion is also unclear, with recurrences occurring in $70 \%$ within 1 year of stopping transfusion programs of $1-2$ years ${ }^{25}$ and in $50 \%$ within 1 year of stopping transfusion programs of $5-12$ years, ${ }^{28}$ a higher frequency than suggested by the natural history data, ${ }^{17,18}$ suggesting that stopping transfusion actually raises the risk of recurrent stroke. The STOP 2 randomized study, which sought to assess the safety of stopping chronic transfusion after a minimal duration of 24 transfusions, was terminated prematurely because of the higher rate of highrisk TCD or occurrence of stroke in the transfusion-halted group. ${ }^{29}$
These observations have led to suggestions that transfusion should be continued for life, raising the risks of long-term complications such as iron overload and red cell alloimmunization as well as with an estimated cost, computed in the year 2000 , at US $\$ 40,000$ per patient per year. ${ }^{30}$

\section{Acute chest syndrome}

The acute chest syndrome has a complex pathology with elements of infection, infarction, fat embolism, and pulmonary sequestration and is a major contributor to deaths after the age of 2 years. Rapidly deteriorating dyspnea, clinical and radiological signs, and pulse oximetry characterize acute pulmonary sequestration which is a life-threatening emergency. Acute dyspnea associated with rapidly increasing, widespread pulmonary opacity may be dramatically reversed by exchange transfusion, ${ }^{31}$ which has been recommended within 48 hours. ${ }^{32,33}$ The incidence of acute chest syndrome and bone pain crisis was significantly reduced in transfused patients in the Stroke Prevention Trial. ${ }^{34}$

\section{Bone pain crises}

Bone pain crisis, a characteristic feature of sickle cell disease, usually attributable to avascular necrosis of the bone marrow, is often precipitated by skin cooling, stress, and infection and is more common in the last 3 months of pregnancy and the immediate postpartum period. Bone pain crises were reduced in a prospective randomized trial of chronic transfusion in pregnancy, ${ }^{35}$ in the STOP trial, ${ }^{34}$ and in an earlier trial with less aggressive transfusion maintaining $\mathrm{HbS}$ levels below $50 \%{ }^{36}$ Although these observations are consistent with a beneficial effect of transfusion in the bone pain crisis, no data are available from a controlled clinical trial.

\section{Perioperative management}

The risks of serious morbidity and occasionally mortality which complicated surgery and anesthesia in the past have improved greatly, but it is unclear whether this is due to better general management or the increasing use of transfusion. Acute transfusion, repeated transfusion, and partial exchange transfusion have been advocated 10-15 days prior to ${ }^{37}$ or immediately before surgery, ${ }^{38}$ but comparison of transfusion techniques failed to reveal perioperative differences. ${ }^{39}$ The first controlled trial found no perioperative differences between aggressive and conservative transfusion, ${ }^{40}$ but their protocol assumed that transfusion was essential and there was no non-transfusion arm in their study. The fundamental question of whether transfusion was necessary remained unanswered, since the morbidity was no greater in centers 
not using preoperative transfusion. ${ }^{41-43}$ The first randomized controlled trial comparing 34 patients with preoperative transfusion with 33 patients with no transfusion found a significant reduction $(P=0.023)$ in acute chest syndrome ${ }^{44}$ but was terminated prematurely on the basis of an interim statistical analysis. A cost-effectiveness study in the same trial favored the transfusion group. ${ }^{45}$ The most recent review and meta-analysis of the literature on the effect of transfusion on perioperative morbidity in sickle cell disease ${ }^{46}$ concluded that the available data did not allow clear conclusions.

\section{Pregnancy}

Pregnancy in SS disease is associated with more frequent spontaneous abortions, stillbirths, and low-birth weight babies. Mothers have increased bone pain crises and acute chest syndrome especially in the last trimester and immediate postpartum period and a greater chance of dying. Early reports noted symptomatic improvement with transfusion, ${ }^{47}$ and Kobak et $\mathrm{al}^{48}$ observed that half the mothers surviving pregnancy had had multiple transfusions. Ricks ${ }^{49,50}$ recommended exchange transfusion 4-6 weeks before labor, and partial exchange transfusion has been increasingly used in the management of pregnancy. ${ }^{51,52}$ The undisputed improvement in pregnancy outcome in many patients over the last 40 years has been attributed to the increased use of transfusion, but a similar improvement has occurred in centers not using prophylactic transfusion. ${ }^{53-55}$ There were no differences in fetal outcome between mothers commencing transfusion before and after 20 weeks, ${ }^{56}$ and the first controlled trial of transfusion showed reduced maternal morbidity but no effect on fetal outcome in terms of survival or birth weight. ${ }^{35}$ Although transfusion during pregnancy may reduce maternal morbidity, ${ }^{57}$ fetal outcome is not improved, ${ }^{58}$ and there remains a lack of properly controlled clinical trials. ${ }^{59}$

\section{Other clinical features}

Claims that transfusion may enhance resolution of major episodes of priapism ${ }^{60,61}$ are not supported by the available data. Blood transfusion has also been proposed for the therapy of chronic leg ulcers, ${ }^{62}$ but no trial data are available.

\section{Problems with transfusions}

Occasionally, problems may occur with simple top-up transfusions in ASS or the aplastic crisis with acutely lowered hemoglobin levels, but these are greatly magnified with the higher levels of blood exposure in chronic transfusion programs. These problems include iron overload, delayed hemolytic transfusion reactions, red cell alloimmunization, transfusion-acquired infections, maintaining venous access, and other side effects.

\section{Iron overload}

Each $300 \mathrm{~mL}$ unit of blood used in transfusion is estimated to contain $225 \mathrm{mg}$ of iron. With the widespread use and greater duration of chronic transfusion, there is increasing concern on iron deposition in the liver and conduction bundles of the heart. Attempts to address this problem have included reducing the rate of iron accumulation by modifying transfusion methods and the use of chelation to remove iron present already in the body. Iron accumulation may be reduced by less rigorous target $\mathrm{HbS}$ levels, ${ }^{36,63}$ automated red cell exchange (erythrocytapheresis), which may delay or even reverse iron accumulation, ${ }^{64,65}$ and partial manual exchange transfusion. ${ }^{66}$

Chelation is usually commenced when serum ferritin levels exceed $1000 \mathrm{ng} / \mathrm{mL}$ and traditionally depended on subcutaneous deferoxamine (DFO), which has a half-life in the plasma measured in minutes and has to be given by continuous subcutaneous injection overnight for 5-7 nights weekly. It is expensive, difficult to administer, and limited by compliance especially during adolescence. It was hoped that some of these disadvantages would be overcome by the oral chelator, deferiprone (DFP), with a 2-hour half-life requiring dosing 3 times daily and deferasirox (DFX; Exjade, Novartis International AG, Basel, Switzerland) which lasts 24 hours and requires daily administration. Both molecules are uncharged and so theoretically would have easier access to intracellular iron compared to the charged molecule of DFO-iron complex. The excretion of DFP-iron complexes is predominantly through the urine, ${ }^{67}$ whereas the DFX is excreted through the stools. The features and side effects of the 2 oral chelators and of DFO have been compared with those of an "ideal chelator" by Neufeld. ${ }^{68}$ The short-term safety of DFX appears acceptable, ${ }^{69}$ but data on longer term exposure are limited, ${ }^{70}$ although these concerns may have been allayed by a recent report of a 4-year follow-up. ${ }^{71}$ Despite the potential advantages of DFX, compliance may still be a problem because of the unpleasant taste. $^{72}$ The management of transfusional iron overload in sickle cell disease has been recently reviewed. ${ }^{73}$

\section{Delayed hemolytic transfusion reactions}

These constitute a potentially serious problem being reported in $14-44 \%$ of patients with antibodies. ${ }^{74,75}$ Presenting with fever, myalgia, severe bone pain, dark urine/hemoglobinuria, increased anemia, and often reticulocytepenia, they may mimic painful crises, and there is some controversy about the role of red cell alloimmunization in these events. ${ }^{76} \mathrm{~A}$ review 
of the UK experience ${ }^{77}$ found major morbidity in 10 patients and death in 1 patient with sickle cell disease, and a retrospective analysis of 99 episodes in France reported death in $6 \% .{ }^{78}$

\section{Red cell alloimmunization}

Alloimmunization is a major problem in chronic transfusion therapy in sickle cell disease. The overall rate in the Cooperative Study in the US was $18.6 \%$ and resulted from multiple antibodies in over $50 \%$ of alloimmunized subjects. ${ }^{79}$ Most antibodies were of the Rh (especially C, E), Kell (K), Duffy (Fy), and Kidd (Jk) groups tending to reflect differences between the predominantly Caucasian donors and Black recipients. ${ }^{80}$ Use of selected donors ${ }^{81,82}$ may reduce this problem, and closer racial matching of donor and recipient populations may have contributed to the lower alloimmunization rates of $12.9 \%$ reported from Brazil ${ }^{83}$ and the $2.6 \%$ reported from Jamaica, ${ }^{84}$ although high rates of alloimmunization persisted in the US despite racial matching of donors and recipients ${ }^{85}$ Alloimmunization rates have fallen with more extensive phenotype matching, rates of $18-76 \%$ being reported with standard matching by $\mathrm{ABO}$ and $\mathrm{Rh}$ groups, $5-14 \%$ with some phenotype matching for C, E, and $\mathrm{K}$ antigens, and $7 \%$ with more extended matching ${ }^{86}$ and extensive matching reported no alloimmunization within 40 patients monitored at a single institution. ${ }^{87}$ To reduce alloimmunization, red cell phenotyping has been proposed prior to the first transfusion followed by matching at least the Rh and Kell groups ${ }^{88}$ but a retrospective study found similar alloimmunization rates in US centers with or without extended phenotype matching. ${ }^{89}$ Even with extended phenotyping, alloimmunization continues, ${ }^{90}$ and the complex field of alloimmunization in sickle cell disease has been extensively reviewed. ${ }^{85,91,92}$ Further concerns on the significance of alloimmunization resulted from a recent study showing that alloimmunized patients were more prone to chronic pain, end-organ damage, and shortened survival. ${ }^{93}$ Post-transfusional monitoring may be helpful in the detection of new antibodies.

\section{Transfusion-acquired infections}

These are inversely related to the diligence of diagnostic screening, and the risks of transfusion-acquired hepatitis $\mathrm{B}$ and $\mathrm{C}$ and of HIV and human T-lymphotropic virus have been greatly reduced, although the infections may still occur. Potential threats also persist with viral agents such as parvovirus B19. Recent review of transfusion safety in the UK indicated that the rates of infections had fallen substantially and that the greatest risk was clerical error. ${ }^{77}$ Malaria may be acquired by transfusion of malarial parasites, with a Ghanaian study finding parasites in $11 \%$ of transfused blood units, ${ }^{94}$ and cases may occur in traditionally non-malarial areas. ${ }^{95}$

\section{Venous access}

Chronic transfusion requiring venous access every 3-4 weeks clearly compromises the available veins, yet limited data are available on the frequency of implantable ports or catheters. These procedures accounted for 86 of 1033 (8.6\%) of all surgeries in a trial of preoperative transfusion, ${ }^{40}$ and it is well recognized that these ports are prone to infection, thrombosis, and embolism, ${ }^{96,97}$ which may require their removal. ${ }^{98} \mathrm{~A}$ summary of earlier studies and a retrospective, single-institution study still did not provide prevalence data but reported that infections and thrombotic problems were more common among adults than children. ${ }^{99}$

\section{Transfusion reactions}

Non-hemolytic transfusion reactions used to occur with approximately $1 \%$ of blood units and in $10-40 \%$ of patients with repeat transfusions ${ }^{80}$ Eighty-five percent of patients receiving more than 50 transfusions demonstrated antibodies to HLA or platelet antigens, ${ }^{100}$ but this has been markedly reduced with leukocyte-depleted blood.

\section{Supplies of suitable blood}

In countries with well-developed blood bank services, suitable blood is generally readily available, although alloimmunization may limit the availability of compatible units. In countries with less well-developed facilities, obstacles to the provision of chronic transfusion programs ${ }^{101}$ include the limited availability of blood and lack of resources for extended cross matching. The latter may increase the risks of alloimmunization, although these may be reduced by the better racial matching of donors and recipients.

\section{Methods of transfusion}

\section{Simple transfusion}

This is the method of choice for the acutely lowered hemoglobin levels in ASS and the aplastic crisis, and the chronically lowered hemoglobin levels in chronic renal failure. Packed red cells are usually used, and washed red cells or special filters may reduce transfusion reactions to white cells or platelet antigens.

\section{Chronic transfusion program}

Used increasingly for a variety of cerebrovascular complications, this requires transfusion every 3-4 weeks and is designed to maintain $\mathrm{HbS}$ levels below $30 \%$. It may be 
performed by recurrent simple transfusions, but attempts to reduce iron accumulation have led to exchange transfusions, which may be performed manually or by automated methods. Donor blood should be confined to the normal AA genotype, since although theoretically AS-genotype blood may be adequate in improving flow, it complicates the assessment of $\mathrm{HbS}$ levels.

\section{Manual methods}

A simple early method consisted of removal of $500 \mathrm{~mL}$ blood followed by infusion of 2 units of donor cells which achieved a 30\% exchange in 90 minutes. ${ }^{102}$ More recent techniques generally use 2 intravenous lines with simultaneous or sequential withdrawal of SS blood and its replacement by donor AA cells. ${ }^{103,104}$ However, although manual procedures are effective in conducting exchange, they are tedious and time-consuming.

\section{Automated methods}

Machines performing centrifugal separation of red blood cells provide a rapid and efficient method of performing partial exchange transfusion. ${ }^{61,105,106}$ Two types of machines are in common use, the discontinuous- and continuous-flow models.

Discontinuous-flow cell separators act as batch processors, pumping blood from the patient's arm, centrifuging it to separate red cells from the plasma, discarding the red cells, and returning the plasma to the patient along with donor cells. A standard procedure of 5-6 cycles achieves a 50\% exchange in approximately 140 minutes. ${ }^{107}$ Continuous-flow separators use 2 intravenous lines, one extracting blood and the other returning the processed blood to the patient. Controlling rates of inflow and outflow ensures that the patient's blood volume does not vary during the procedure. A 6-unit exchange can be completed in 70 minutes, ${ }^{108}$ a $72 \%$ exchange within 2.5 hours, ${ }^{109}$ and a $90 \%$ exchange in 3.5 hours. ${ }^{110}$ Such rapid exchange invariably results in a sharp increase in oxygen affinity which may cause problems, ${ }^{110}$ although it was well tolerated in other series. ${ }^{105,106,111}$ In summary, discontinuousflow separators are small, mobile, simple to operate, relatively cheap, and require only 1 intravenous line. Continuous-flow separators are more complex and expensive, and more efficient but require 2 intravenous lines with large needles or catheters capable of carrying the large flows. Supplies for both cell separator techniques are considerably more expensive than manual methods but require less professional time.

\section{Acute exchange transfusion}

With rapidly progressive, life-threatening pathology, it may be necessary to conduct immediate exchange transfusion, and this is most commonly indicated in acute pulmonary sequestration or the acute phase of a stroke. Replacement of the HbS-containing cells in these situations may prevent the progression of pathology, and sometimes, dramatic reversals occur in clinical and radiological features indicating that some cases of acute pulmonary sequestration are a reversible vascular phenomenon.

\section{Choice of blood}

Chronic transfusion programs with the objective of lowering $\mathrm{HbS}$ levels may be more effective and simpler to monitor if donor blood is restricted to the HbAA genotype. Fresh blood should persist for longer in the recipient's circulation and may reduce transfusion requirements. Concentrated young red cells (neocytes) have been used for transfusion programs in thalassemia ${ }^{112}$ but require large resources of blood from which to harvest the neocytes. The use of neocytes and a supertransfusion regimen has been shown to reduce iron accumulation in thalassemia, ${ }^{113}$ but no data are available on this approach in sickle cell disease.

\section{Optimal hemoglobin level}

Generally, patients with SS disease are well adapted to their steady-state hemoglobin level of 6-9 g/dL. In acutely lowered and symptomatic anemia, transfusion support should be the minimal required to maintain oxygen delivery. In the aplastic crisis due to parvovirus B19 infection, bone marrow activity is usually about to recommence by the time of clinical presentation, and in the author's experience, a single unit is adequate. Special care is required in transfusion support for ASS when release of sequestered red cells from the spleen added to those given by transfusion may lead to unexpectedly high hemoglobin levels and sometimes resulting in bone pain. Chronic transfusion programs are usually monitored by the HbS level, and the total hemoglobin is a secondary consideration. Sudden changes in hematocrit may have serious implications for renal function, and excessive transfusion has caused death from cerebral hemorrhage. ${ }^{114}$

\section{Conclusion}

Reducing the levels of $\mathrm{HbS}$ lessens the likelihood of pathology in sickle cell disease, and theoretically, regular transfusions of HbAA blood from birth would prevent the manifestations of the disease. In practice, the many problems with chronic transfusion make this unrealistic, and a balance must be struck between the advantages and disadvantages of chronic transfusion. The final position will be determined by many factors such as the ready availability of blood, 
resources for extended blood group matching, facilities for performing exchange transfusion, maintaining of venous access, the availability of effective chelation, and the option of alternative therapies. Chronic transfusion programs are more readily achieved in major centers in the US and Europe but are a daunting prospect for developing societies because of the limited medical infrastructure and the large numbers of patients with sickle cell disease.

Indications for blood transfusion in the management of sickle cell disease present a spectrum from widespread acceptance, areas considered controversial, and those where there is almost no supporting evidence. Clearly beneficial is the use of top-up transfusion for acutely or chronically lowered hemoglobin levels, and convincing data support the use of chronic transfusion programs in the prevention of primary or secondary stroke. Controversial areas include the use of transfusion preoperatively, in the management of pregnancy, and in clinical complications such as chronic leg ulcers or priapism. Most controversial is the use or "top-up" transfusions at steady-state hemoglobin levels, some physicians believing that this may be beneficial. Inevitably, the clinically acceptable point in this spectrum is influenced by the sophistication of transfusion services and ready availability of blood. Despite convincing evidence, therapies such as chronic transfusion for the prevention of primary or secondary stroke may not be feasible in some societies because of the limited availability of blood and of resources available for iron chelation. It must be accepted that transfusion is not universally benign but carries with it risks that are multiplied with the transfusion loads associated with chronic transfusion programs. Whether these risks are justified must be determined by the natural history of the underlying complication and by the availability of alternative therapies. In communities where strokes are a major manifestation of sickle cell disease but the available resources make chronic transfusion unrealistic, hydroxyurea may offer an alternative therapy, ${ }^{115,116}$ and may also reduce transfusion requirements. In the prophylaxis of recurrent ASS or in the treatment of chronic hypersplenism, splenectomy offers a viable alternative to the dangers of chronic transfusion. It is true that these risks may be reduced by extended phenotype matching, at some cost, but even then, is it necessary to take these risks if alternative therapies are available? More information is needed on the natural history of the complications of sickle cell disease and of alternative therapies before the role and risks of transfusion therapy can be clearly defined.

The African forms of sickle cell disease have more severe features than those with the Asian haplotype where frequent alpha thalassemia and persistence of $\mathrm{HbF}$ may protect against some of the serious early pathologies of the disease. More information is needed on the Asian haplotype, ${ }^{117}$ before the role of transfusion can be determined in that population, and transfusion in the steady state $^{118}$ requires justification. As the Asian haplotype of SS disease becomes better documented and understood, the role of transfusion therapy in its management will be more readily defined.

\section{Disclosure}

The author reports no conflicts of interest in this work.

\section{References}

1. Nagel RL, Fabry ME, Pagnier J, et al. Hematologically and genetically distinct forms of sickle cell anemia in Africa. The Senegal type and the Benin type. N Engl J Med. 1985;312(14):880-884.

2. Kulozik AE, Wainscoat JS, Serjeant GR, et al. Geographical survey of $\beta S$-globin gene haplotypes: evidence for an independent Asian origin of the sickle-cell mutation. Am J Hum Genet. 1986;39(2):239-244.

3. Serjeant G, Serjeant B, Stephens A, et al. Determinants of haemoglobin level in steady-state homozygous sickle cell disease. Br J Haematol. 1996;92(1):143-149.

4. Hayes RJ, Beckford M, Grandison Y, Mason K, Serjeant BE, Serjeant GR. The haematology of steady state homozygous sickle cell disease. Frequency distributions, variation with age and sex, longitudinal observations. Br J Haematol. 1985;59(2):369-382.

5. Kar BC, Satapathy RK, Kulozik AE, et al. Sickle cell disease in Orissa State, India. Lancet. 1986;2(8517):1198-1201.

6. Bellingham AJ, Huehns ER. Compensation in haemolytic anaemias caused by abnormal haemoglobins. Nature. 1968;218(5145):924-926.

7. Badaloo AV, Singhal A, Forrester TE, Serjeant GR, Jackson AA. The effect of splenectomy for hypersplenism on whole body protein turnover, resting metabolic rate and growth in sickle cell disease. Eur J Clin Nutr. 1996;50(10):672-675.

8. Emond AM, Collis R, Darvill D, Higgs DR, Maude GH, Serjeant GR. Acute splenic sequestration in homozygous sickle cell disease: natural history and management. J Pediatr. 1985;107(2):201-206.

9. Stevens MCG, Hayes RJ, Vaidya S, Serjeant GR. Fetal hemoglobin and clinical severity of homozygous sickle cell disease in early childhood. J Pediatr. 1981;98(1):37-41.

10. Pearson HA, Cornelius EA, Schwartz AD, Zelson JH, Wolfson SL, Spencer RP. Transfusion reversible functional asplenia in young children with sickle-cell anemia. N Engl J Med. 1970;283(7):334-337.

11. Kinney TR, Ware RE, Schultz WH, Filston HC. Long-term management of splenic sequestration in children with sickle cell disease. $J$ Pediatr. 1990;117(2 Pt 1):194-199.

12. Rao S, Pang E. Transfusion therapy for subacute splenic sequestration in sickle cell disease. Blood. 1982;60:48a.

13. Owusu-Ofori S, Remmington T. Splenectomy versus conservative management for acute sequestration crises in people with sickle cell disease. Cochrane Database Syst Rev. 2013;(5):CD003425.

14. Serjeant GR, Topley JM, Mason K, et al. Outbreak of aplastic crises in sickle cell anaemia associated with parvovirus-like agent. Lancet. 1981;2(8247):595-597.

15. Serjeant BE, Hambleton IR, Kerr S, Kilty CG, Serjeant GR. Haematological response to parvovirus B19 infection in sickle-cell disease. Lancet. 2001;358(9295):1779-1780.

16. Wright JG, Hambleton IR, Thomas PW, Duncan ND, Venugopal S, Serjeant GR. Postsplenectomy course in homozygous sickle cell disease. J Pediatr. 1999;134(3):304-309. 
17. Balkaran B, Char G, Morris JS, Thomas PW, Serjeant BE, Serjeant GR. Stroke in a cohort study of patients with homozygous sickle cell disease. J Pediatr. 1992;120(3):360-366.

18. Powars D, Wilson B, Imbus C, Pegelow C, Allen J. The natural history of stroke in sickle cell disease. Am J Med. 1978;65(3):461-471.

19. Pegelow CH, Adams RJ, McKie V, et al. Risk of recurrent stroke in patients with sickle cell disease treated with erythrocyte transfusions. J Pediatr. 1995;126(6):896-899.

20. Adams RJ, McKie VC, Carl EM, et al. Long-term stroke risk in children with sickle cell disease screened with transcranial Doppler. Ann Neurol. 1997;42(5):699-704.

21. Adams RJ, McKie VC, Hsu L, et al. Prevention of first stroke by transfusions in children with sickle cell anemia and abnormal results on transcranial ultrasonography. N Engl J Med. 1998;339(1):5-11.

22. Lee MT, Piomelli S, Granger S, et al; STOP Study Investigators. Stroke prevention trial in sickle cell anemia (STOP): extended follow-up and final results. Blood. 2006;108(3);847-852.

23. DeBaun MR, Gordon M, McKinstry RC, et al. Controlled trial of transfusions for silent cerebral infarcts in sickle cell anemia. $N$ Engl J Med. 2014;371(18):699-710.

24. Buchanan GR, Bowman WP, Smith SJ. Recurrent cerebral ischemia during hypertransfusion therapy in sickle cell anemia. J Pediatr. 1983;103(6):921-923.

25. Wilimas J, Goff JR, Anderson HR Jr, Langston JW, Thompson E. Efficacy of transfusion therapy for one to two years in patients with sickle cell disease and cerebrovascular accidents. J Pediatr. 1980;96(2):205-208.

26. Hulbert ML, McKinstry RC, Lacey JL, et al. Silent cerebral infarcts occur despite regular blood transfusion therapy after first strokes in children with sickle cell disease. Blood. 2011;117(3):772-779.

27. Mirre E, Brousse V, Berteloot L, et al. Feasibility and efficacy of chronic transfusion for stroke prevention in children with sickle cell disease. Eur J Haematol. 2010;84(3):259-265.

28. Wang WC, Kovnar EH, Tonkin IL, et al. High risk of recurrent stroke after discontinuance of five to twelve years of transfusion therapy in patients with sickle cell disease. J Pediatr. 1991;118(3):377-382.

29. Adams RJ, Brambilla D; Optimizing Primary Stroke Prevention in Sickle Cell Anemia (STOP 2) Trial Investigators. Discontinuing prophylactic transfusions used to prevent stroke in sickle cell disease. N Engl J Med. 2005;353(26):2769-2778.

30. Wayne AS, Schoenike SE, Pegelow CH. Financial analysis of chronic transfusion for stroke prevention in sickle cell disease. Blood. 2000;96(7):2369-2372.

31. Lanzkowsky P, Shende A, Karayalcin G, Kim YJ, Aballi A. Partial exchange transfusion in sickle cell anemia. Use in children with serious complications. Am J Dis Child. 1978;132(12):1206-1208.

32. Davies SC, Luce PJ, Win AA, Rioredan JF, Brozovic M. Acute chest syndrome in sickle-cell disease. Lancet. 1984;1(8367):36-38.

33. Mallouh AA, Asha M. Beneficial effect of blood transfusion in children with sickle cell chest syndrome. Am J Dis Child. 1988;142(2):178-182.

34. Miller ST, Wright E, Abboud M, et al; STOP Investigators. Impact of chronic transfusion on incidence of pain and acute chest syndrome during the Stroke Prevention Trial (STOP) in sickle-cell anemia. $J$ Pediatr. 2001;139(6):785-789.

35. Koshy M, Burd L, Wallace D, Moawad A, Baron J. Prophylactic red cell transfusions in pregnant patients with sickle cell disease. A randomized cooperative study. $N$ Engl J Med. 1988;319(22):1447-1452.

36. Miller ST, Jensen D, Rao SP. Less intensive long-term transfusion therapy for sickle cell anemia and cerebrovascular accident. J Pediatr. 1992;120(1):54-57.

37. Bentley PG, Howard ER. Surgery in children with homozygous sickle cell anaemia. Ann R Coll Surg Engl. 1979;61(1):55-58.

38. Janik J, Seeler RA. Perioperative management of children with sickle cell hemoglobinopathy. J Pediatr Surg. 1980;15(12):117-120.

39. Fullerton MW, Philippart AI, Sarnaik S, Lusher JM. Perioperative exchange transfusion in sickle cell anemia. J Pediatr Surg. 1981;16(3):297-300.
40. Vichinsky EP, Haberkern CM, Neumayr L, et al. A comparison of conservative and aggressive transfusion regimens in the perioperative management of sickle cell disease. The Preoperative Transfusion in Sickle Cell Disease Study Group. NEngl J Med. 1995;333(4):206-213.

41. Homi J, Reynolds J, Skinner A, Hanna W, Serjeant GR. General anaesthesia in sickle-cell disease. Br Med J. 1979;1(6178):1599-1601.

42. Bischoff RJ, Williamson A 3rd, Dalali MJ, Rice JC, Kerstein MD. Assessment of the use of transfusion therapy perioperatively in patients with hemoglobinopathies. Ann Surg. 1988;207(4):434-438.

43. Griffin TC, Buchanan GR. Elective surgery in children with sickle cell disease without preoperative blood transfusion. J Pediatr Surg. 1993;28(5):681-685.

44. Howard J, Malfroy M, Llewelyn C, et al. The Transfusion Alternatives Preoperatively in Sickle Cell Disease (TAPS) study: a randomised, controlled, multicentre clinical trial. Lancet. 2013;381(9870):930-938.

45. Spackman E, Sculpher M, Howard J, et al. Cost-effectiveness analysis of preoperative transfusion in patients with sickle cell disease using evidence from the TAPS trial. Eur J Haematol. 2014;92(3):249-255.

46. Alotaibi GS, Alsaleh K, Bolster L, McMurtry MS, Wu C. Preoperative transfusion in patients with sickle cell disease to prevent perioperative complications: a systematic review and meta-analysis. Hematology. 2014:19(8):463-471

47. Spivak M. Sickle-cell anemia complicated by pregnancy. Am J Obstet Gynecol. 1945;50(4):442-446.

48. Kobak AJ, Stein PJ, Daro AF. Sickle-cell anemia in pregnancy. A review of the literature and report of six cases. Am JObstet Gynecol. 1941;41(5):811-821.

49. Ricks P. Exchange transfusion in sickle cell anemia and pregnancy. Obstet Gynecol. 1965;25:117-119.

50. Ricks P Jr. Further experience with exchange transfusion in sickle cell anemia and pregnancy. Am J Obstet Gynecol. 1968;100(8): 1087-1091.

51. Cunningham FG, Pritchard AJ, Mason R, Chase G. Prophylactic transfusions of normal red blood cells during pregnancies complicated by sickle cell hemoglobinopathies. Am J Obstet Gynecol. 1979;135(7):994-1003.

52. Morrison JC, Schneider JM, Whybrew WD, Bucovaz ET, Menzel DM. Prophylactic transfusions in pregnant patients with hemoglobinopathies. Obstet Gynecol. 1980;56(3):274-280.

53. Charache S, Scott JC, Niebyl J, Bonds D. Management of sickle cell disease in pregnant patients. Obstet Gynecol. 1980;55(4):407-410.

54. Miller JM Jr, Horger EO 3rd, Key TC, Walker EM Jr. Management of sickle hemoglobinopathies in pregnant patients. Am J Obstet Gynecol. 1981;141(3):237-241.

55. Powars DR, Sandhu M, Niland-Weiss J, Johnson C, Bruce S, Manning PR. Pregnancy in sickle cell disease. Obstet Gynecol. 1986;67(2):217-228.

56. Tuck SM, Brewster EM, Studd JWW, James CE, Pearson TC. Prophylactic blood transfusion in maternal sickle cell syndromes. Br J Obstet Gynaecol. 1987;94(2):121-125.

57. Asma S, Kozanoglu I, Tarim E, et al. Prophylactic red blood cell exchange may be beneficial in the management of sickle cell disease in pregnancy. Transfusion. 2015;55(1):36-44.

58. Howard RJ, Tuck SM, Pearson TC. Pregnancy in sickle cell disease in the UK: results of a multicentre survey of the effect of prophylactic blood transfusion on maternal and fetal outcome. Br JObstet Gynaecol. 1995;102(12):947-951.

59. Okusanya BO, Oladapo OT. Prophylactic versus selective blood transfusion for sickle cell disease in pregnancy. Cochrane Database Syst Rev. 2013;(12):CD010378.

60. Seeler RA. Intensive transfusion therapy for priapism in boys with sickle cell anemia. J Urol. 1973;110(3):360-361.

61. Rifkind S, Waisman J, Thompson R, Goldfinger D. RBC exchange pheresis for priapism in sickle cell disease. JAMA. 1979;242:2317-2318.

62. Chernoff AI, Shapleigh JB, Moore CV. Therapy of chronic ulceration of the legs associated with sickle cell anemia. JAMA. 1954;155(17):1487-1491. 
63. Cohen AR, Martin MB, Silber JH, Kim HC, Ohene-Frempong K, Schwartz E. A modified transfusion program for prevention of stroke in sickle cell disease. Blood. 1992;79(7):1657-1661.

64. Kim HC, Dugan NP, Silber JH, et al. Erythrocytapheresis therapy to reduce iron overload in chronically transfused patients with sickle cell disease. Blood. 1994;83(4):1136-1142.

65. Hilliard LM, Williams BF, Lounsbury AE, Howard TH. Erythrocytapheresis limits iron accumulation in chronically transfused sickle cell patients. Am J Hematol. 1998;59(1):28-35.

66. Savage WJ, Reddoch S, Wolfe J, Casella JF. Partial manual exchange reduces iron accumulation during chronic red cell transfusion for sickle cell disease. J Pediatr Hematol Oncol. 2013;35(6):434-436.

67. Collins AF, Fassos FF, Stobie S, et al. Iron-balance and dose-response studies of the oral chelator 1,2-dimethyl-3-hydro-xypyrid-4-one (L1) in iron loaded patients with sickle cell disease. Blood. 1994;83:2329-2333.

68. Neufeld EJ. Oral chelators deferasirox and deferiprone for transfusional iron overload in thalassemia major: new data, new questions. Blood. 2006;107(9);3436-3441.

69. Vichinsky E, Torres M, Minniti CP, et al. Efficacy and safety of deferasirox compared with deferoxamine in sickle cell disease: two-year results including pharmacokinetics and concomitant hydroxyurea. Am J Hematol. 2013;88(12):1068-1073.

70. Meerpohl JJ, Schell LK, Rucker G, et al. Deferasirox for managing transfusional iron overload in people with sickle cell disease. Cochrane Database Syst Rev. 2014;5:CD007477.

71. Vlachaki E, Mainou M, Bekiari E, Vetsiou E, Tsapas A. Safety and efficacy of 4 years of deferasirox treatment for sickle cell disease patients. Hemoglobin. 2013;37(1):94-100.

72. Tsouana E, Kaya B, Gadong N, et al. Deferasirox for iron chelation in multitransfused children with sickle cell disease; long-term experience in the East London clinical hemoglobinopathy network. Eur J Haematol. 2015;94(4):336-342.

73. Porter J, Garbowski M. Consequences and management of iron overload in sickle cell disease. Hematology Am Soc Hematol Educ Program. 2013;2013:447-456.

74. Cox JV, Steane E, Cunningham G, Frenkel EP. Risk of alloimmunization and delayed hemolytic transfusion reactions in patients with sickle cell disease. Arch Intern Med. 1988;148(11):2485-2489.

75. Vichinsky EP, Earles A, Johnson RA, Hoag MS, Williams A, Lubin B. Alloimmunization in sickle cell anemia and transfusion of racially unmatched blood. N Engl J Med. 1990;322(23):1617-1621.

76. de Montalembert M, Dumont MD, Heilbronner C, et al. Delayed hemolytic transfusion reaction in children with sickle cell disease. Haematologica. 2011;96(6):801-807.

77. Bolton-Maggs PHB, Cohen H. Serious hazards of transfusion (SHOT) hemovigilance and progress is improving transfusion safety. $\mathrm{Br} J$ Haematol. 2013;163:303-314.

78. Habibi A, Mekontso-Dessap A, Guillaud C, et al. Delayed hemolytic transfusion reaction in adult sickle-cell disease: presentations, outcomes, and treatments of 99 referral center episodes. Am J Hematol. Epub 2016 Jun 27.

79. Rosse WF, Gallagher D, Kinney TR, et al. Transfusion and alloimmunization in sickle cell disease. The Cooperative Study of Sickle Cell Disease. Blood. 1990;76(7):1431-1437.

80. Wayne AS, Kevy SV, Nathan DG. Transfusion management of sickle cell disease. Blood. 1993;81(5):1109-1123.

81. Sosler SD, Jilly BJ, Saporito C, Koshy M. A simple, practical model for reducing alloimmunization in patients with sickle cell disease. $\mathrm{Am}$ J Hematol. 1993;43(2):103-106.

82. Sandler SG, Mallory D, Wolfe JS, Byrne P, Lucas DM. Screening with monoclonal anti-Fy3 to provide blood for phenotype-matched transfusions for patients with sickle cell disease. Transfusion. 1997;37(4):393-397.

83. Moreira Júnior G, Bordin JO, Kuroda A, Kerbauy J. Red blood cell alloimmunization in sickle cell disease: the influence of racial and antigenic pattern differences between donors and recipients in Brazil. Am J Hematol. 1996;52(3):197-200.
84. Olujohungbe A, Hambleton I, Stephens L, Serjeant B, Serjeant G. Red cell antibodies in patients with homozygous sickle cell disease: a comparison of patients in Jamaica and the United Kingdom. $\mathrm{Br} J$ Haematol. 2001;113(3):661-665.

85. Chou ST, Jackson T, Vege S, Smith-Whitley K, Friedman DF, Westhoff CM. High prevalence of red blood cell alloimmunization in sickle cell disease despite transfusion from Rh-matched minority donors. Blood. 2013;122(6):1062-1071.

86. Lasalle-Williams M, Nuss R, Le T, et al. Extended rde blood cell antigen matching for transfusions in sickle cell disease: a review of a 14-year experience from a single center. Transfusion. 2011;51(8):1732-1739.

87. Tahhan HR, Holbrook CT, Braddy LR, Brewer LD, Christie JD. Antigen-matched donor blood in the transfusion management of patients with sickle cell disease. Transfusion. 1994;34(7):562-569.

88. Vichinsky EP, Luban NL, Wright E, et al. Prospective RBC phenotype matching in a stroke-prevention trial in sickle cell anemia: a multicenter transfusion trial. Transfusion. 2001;41(9):1086-1092.

89. Miller ST, Kim HY, Weiner DL, et al; Investigators of the Sickle Cell Disease Clinical Research Network (SCDCRN). Red blood cell alloimmunization in sickle cell disease: prevalence in 2010. Transfusion. 2013;53(4):704-709.

90. O’Suoji C, Liem RI, Mack AK, Kingsberry P, Ramsey G, Thompson AA. Alloimmunization in sickle cell anemia in the era of extended red cell typing. Pediatr Blood Cancer. 2013;60(9):1487-1491.

91. Chou ST, Liem RI, Thompson AA. Challenges of alloimmunization in patients with hemoglobinopathies. $\mathrm{Br} J$ Haematol. 2012;159(4):394-404.

92. Yazdanbakhsh K, Ware RE, Noizat-Pirenne, F. Red blood cell alloimmunization in sickle cell disease: pathophysiology, risk factors, and transfusion management. Blood. 2012;120(3):528-537.

93. Telen MJ, Afenyi-Annan A, Garrett ME, et al. Alloimmunization in sickle cell disease: changing antibody specificities and association with chronic pain and decreased survival. Transfusion. 2015;55(6 Pt 2):1378-1387.

94. Allain JP, Assennato SM, Osei EN, et al. Characterization of posttransfusion Plasmodium falciparum infection in semi-immune nonparasitemic patients. Transfusion. Epub 2016 Jun 24.

95. Holtzclaw A, Mrsic Z, Managbanag J, Calvano T, Colombo C. Transfusion-transmitted malaria not preventable by current blood donor screening guidelines: a case report. Transfusion. Epub 2016 Jun 13.

96. Abdul-Rauf A, Gauderer M, Chiarucci K. Long-term central venous access in patients with sickle cell disease. Incidence of thrombotic and infectious complications. J Pediatr Hematol Oncol. 1995;17(4): 342-345.

97. McCready CE, Doughty HA, Pearson TC. Experience with the PortA-Cath in sickle cell disease. Clin Lab Haematol. 1996;18(2):79-82.

98. Alkindi S, Matwani S, Al-Maawali A, Al-Maskari B, Pathare A. Complications of PORT-A-CATH® in patients with sickle cell disease. $J$ Infect Public Health. 2012;5(1):57-62.

99. Shah N, Landi D, Shah R, Rothman J, De Castro LM, Thornburg CD. Complications of implantable venous access devices in patients with sickle cell disease. Am J Hematol. 2012;87(2):224-226.

100. Friedman DF, Lukas MB, Jawad A, Larson PJ, Ohene-Frempong K, Manno CS. Alloimmunization to platelets in heavily transfused patients with sickle cell disease. Blood. 1996;88(8):3216-3222.

101. Osaro E, Charles AT. The challenges of meeting the blood transfusion requirements in Sub-Saharan Africa: the need for the development of alternatives to allogenic blood. J Blood Med. 2011;2:7-21.

102. Anderson R, Cassell M, Mullinax GL, Chaplin H Jr. Effect of normal cells on viscosity of sickle-cell blood: in vitro studies and reports of six years' experience with a prophylactic program of "partial exchange transfusion”. Arch Intern Med. 1963;111:286-294.

103. Morrison JC, Wiser WL. The use of prophylactic partial exchange transfusion in pregnancies associated with sickle cell hemoglobinopathies. Obstet Gynecol. 1976;48(5):516-520.

104. Charache S. Treatment of sickle cell anemia. Annu Rev Med. 1981;32:195-206. 
105. Kernoff LM, Botha MC, Jacobs P. Exchange transfusion in sickle cell disease using a continuous-flow blood cell separator. Transfusion. 1977;17(3):269-271.

106. Kleinman S, Thompson-Breton R, Breen D, Hurvitz C, Goldfinger D. Exchange red blood cell pheresis in a pediatric patient with severe complications of sickle cell anemia. Transfusion. 1981;21(4): 443-446.

107. Klein HG, Garner RJ, Miller DM, Rosen SL, Statham NJ, Winslow RM. Automated partial exchange transfusion in sickle cell anemia. Transfusion. 1980;20(5):578-584.

108. Klein HG. Cell separators for red cell exchange. In: Scott RB, editor. Advances in the Pathophysiology, Diagnosis and Treatment of Sickle Cell Disease. New York, NY: Alan R Liss; 1982:109-116.

109. Janes SL, Pocock M, Bishop E, Bevan DH. Automated red cell exchange in sickle cell disease. Br J Haematol. 1997;97(2):256-258.

110. White JM, White YS, Buskard N, Gillies ID. Increasing whole blood oxygen affinity during rapid exchange transfusion: a potential hazard. Transfusion. 1976;16(3):232-236.

111. Key TC, Horger EO 3rd, Walker EM Jr, Mitchum EN. Automated erythrocytopheresis for sickle cell anemia during pregnancy. Am J Obstet Gynecol. 1980;138(7 Pt 1):731-737.
112. Corash LM, Piomelli S, Chen HC, Seaman C, Gross E. Separation of erythrocytes according to age on a simplified density gradient. J Lab Clin Med. 1974;84(1):147-151.

113. Propper RD, Button LN, Nathan DG. New approaches to the transfusion management of thalassemia. Blood. 1980;55(1):55-60.

114. Serjeant G. Blood transfusion in homozygous sickle cell disease - a cautionary tale. Lancet. 2003;361(9639):1659-1660.

115. Hankins JS, McCarville MB, Rankine-Mullings A, et al. Prevention of conversion to abnormal transcranial Doppler with hydroxyurea in sickle cell anemia: a Phase III international randomized clinical trial. Am J Hematol. 2015;90(12):1099-1105.

116. Ware RE, Davis BR, Schultz WH, et al. Hydroxycarbamide versus chronic transfusion for maintenance of transcranial doppler flow velocities in children with sickle cell anaemia-TCD with transfusions changing to hydroxyurea (TWiTCH): a multicentre, open-label, phase 3, non-inferiority trial. Lancet. 2016;387(10019):661-670.

117. Serjeant GR. Evolving locally appropriate models of care. Ind J Med Res. 2016;143(4):405-413.

118. Mehta V, Mistry A, Raicha B, Italia Y, Serjeant G. Transfusion in sickle cell disease: experience from a Gujarat centre. Indian J Pediatr. 2014;81(3):234-237.
International Journal of Clinical Transfusion Medicine

\section{Publish your work in this journal}

International Journal of Clinical Transfusion Medicine is an international, peer-reviewed, open access, online journal publishing clinicalexperimental, policy-making and evidence-based practices of all topics pertaining to clinical transfusion medicine. Original research, short reports, reviews, case reports and commentaries are invited.

\section{Dovepress}

The manuscript management system is completely online and includes a very quick and fair peer-review system, which is all easy to use. Visit http://www.dovepress.com/testimonials.php to read real quotes from published authors.

Submit your manuscript here: https://www.dovepress.com/international-journal-of-clinical-transfusion-medicine-journal 